\title{
Cellular Therapeutics - Living Drugs: A Rising Star at the Horizon of Immunotherapy in Hematology and Oncology
}

\author{
Andreas Humpe ${ }^{\mathrm{a}} \quad$ Ulrike Köhl ${ }^{\mathrm{b}-\mathrm{d}}$

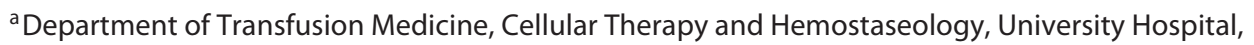 \\ Ludwig-Maximilians-Universität München, Munich, Germany; ${ }^{\mathrm{b}}$ Institute of Cellular Therapeutics, Hannover Medical \\ School (MHH), Hannover, Germany; ' Institute of Clinical Immunology, University Hospital and Medical Faculty, \\ University of Leipzig, Leipzig, Germany; ${ }^{d}$ Fraunhofer Institute for Cell Therapy and Immunology, Leipzig, Germany
}

Until recently, only the transplantation of autologous or allogeneic hematopoietic stem and progenitor cells after conditioning therapies had been well established for more than 4 decades reaching more than 1 million successful transplantations worldwide. During the last years two cellular therapeutics, allogeneic, third-party mesenchymal stromal cells (MSC) and autologous chimeric antigen receptor T cells (CAR-T cells), finally succeeded to prove clinical effectiveness and safety and have now been introduced into the clinic. In August 2016, the German health authorities (Paul Ehrlich Institute) approved an allogeneic MSC product deduced from pooled bone marrow mononuclear cells. Subsequently, data of a clinical trial published in 2018 [1] showed the clinical effectiveness and safety of this living drug. CAR-T-cell treatment in cancer is a challenge with worldwide more than 200 studies at the end of 2016 and exceeding 450 studies to date. In August 2017, the FDA approved the first CAR-T-cell therapy. In addition both drugs can now be purchased commercially in different formulations probably marking a milestone for the fur- ther evaluation and development of such therapies. Therefore several aspects with respect to clinical application as well as potential problems and future developments in this area of living drugs are addressed in this issue of Transfusion Medicine and Hemotherapy.

Elgaz et al. [2] summarize the clinical use of pooled, third-party MSC for patients with acute graft-versus-host disease after transplantation of allogeneic hematopoietic stem and progenitor cells. Aleksandrova et al. [3] present data on the functionality and cell status of CD20 CAR-T cells generated automatically on a special platform. Kretschmer et al. [4] review a potential and promising therapeutic option, CAR-expressing NK cells, in the area of hematology and oncology. Subklewe et al. [5] summarize the actual status of the clinical use of CAR-T cells, and Wennhold et al. [6] review the actual knowledge with respect to the potential clinical use of B-cell-based therapies.

Taken together the articles give a good overview and insight into a new, rapidly growing and changing field of engineering and application of living cellular drugs.

\footnotetext{
References

1 Bader P, Kuçi Z, Bakhtiar S, Basu O, Bug G, Dennis M, et al. Effective treatment of steroid and therapy-refractory acute graft-versushost disease with a novel mesenchymal stromal cell product (MSC-FFM). Bone Marrow Transplant. 2018 Jul;53(7):852-62.

2 Elgaz S, Kuci Z, Kuci S, Bönig HB, Bader P. Clinical use of mesenchymal stromal cells in the treatment of acute GvHD. Transfus Med

3 Aleksandrova K, Leise J, Priesner C, Melk A, Kubaink F, Abken H, Hombach A, Aktas M, Essl M, Bürger I, Kaiser A, Rauser G, Jurk M, Goudeva L, Glienke W, Areseniev L, Esser R, Köhl U. Functionality and cell senescence of CD4/CD8-selected CD20 CAR T Cells manufactured using the automated CliniMACS Prodigy ${ }^{\circledR}$ Platform. Transfus Med Hemother. DOI: $10.1159 / 000495772$.
} Hemother. DOI: 10.1159/000496809.
4 Kretschmer A, Kloess S, Stahl L, Fricke S, Koehl U. CAR-expressing NK cells for cancer retargeting. Transfus Med Hemother. DOI: 101159/000495771.

5 Subklewe $M$, von Bergwelt-Baildon $M$, Humpe A. CAR T cells: a race to revolutionize cancer therapy. Transfus Med Hemother. DOI: $10.1159 / 000496870$.

6 Wennhold K, Shimabukuro-Vornhagen A, von Bergwelt-Baildon M. B-cell-based cancer immunotherapy. Transfus Med Hemother. DOI: $10.1159 / 000496166$.

\section{KARGER}

(C) 2019 S. Karger AG, Basel
Prof. Andreas Humpe

Department of Transfusion Medicine, Cellular Therapeutics and Hemostaseology

University Hospital, LMU Munich, Marchioninistr. 15

DE-81377 Munich (Germany)

E-Mail andreas.humpe@med.uni-muenchen.de 